\title{
Validação de marcadores moleculares associados a genes de resistência à ferrugem-da-folha do trigo
}

\author{
Paulo Roberto Da Silva(1), Sandra Cristina Kothe Milach(2), Vinicius de Albuquerque Sortica ${ }^{(3)}$, Tatiana Boff(1), \\ Sandra Patussi Brammer ${ }^{(4)}$ e Luiz Carlos Federizzi( ${ }^{(3)}$
}

\begin{abstract}
(1)Universidade Federal do Rio Grande do Sul (UFRGS), Programa de Pós-Graduação em Biologia Celular e Molecular, Centro de Biotecnologia do Rio Grande do Sul, Caixa Postal 15.005, CEP 91501-970 Porto Alegre, RS. E-mail: paulo@cbiot.ufrgs.br, tatianaboff@cbiot.ufrgs.br ${ }^{(2)}$ Pioneer Sementes Ltda, Centro de Pesquisa de Passo Fundo, Caixa Postal 3031, CEP 99050-970 Passo Fundo, RS. E-mail: sandra.milach@pioneer.com ${ }^{(3)}$ UFRGS, Departamento de Plantas de Lavoura, Caixa Postal 15.100, CEP 91501-970 Porto Alegre, RS. E-mail: vsortica@hotmail.com, federizi@ufrgs.br (4)Embrapa Trigo, BR 285, Km 294, CEP 99001-970 Passo Fundo, RS. E-mail: sandra@cnpt.embrapa.br
\end{abstract}

\begin{abstract}
Resumo - O objetivo deste trabalho foi validar marcadores moleculares previamente associados a genes que conferem resistência à ferrugem-da-folha, em genótipos brasileiros de trigo. Cinco marcadores STS e SCAR, identificados como associados aos alelos de resistência dos genes $\operatorname{Lr} 1, \operatorname{Lr} 9, \operatorname{Lr} 10$ e $L r 24$, foram avaliados por PCR, em 25 genótipos de trigo com conhecida presença ou ausência desses alelos. O marcador STS, associado ao alelo de resistência do gene $L r l$, não foi eficiente em identificar genótipos brasileiros que possuem este alelo de resistência. Os marcadores STS e SCAR, associados a $\operatorname{Lr} 9, \operatorname{Lr} 10$ e $\operatorname{Lr} 24$, foram eficientes na identificação de plantas que possuem o alelo de resistência desses genes, e podem ser utilizados na seleção por marcadores da resistência à ferrugem-da-folha, em genótipos brasileiros de trigo.
\end{abstract}

Termos para indexação: Puccinia triticina, Triticum aestivum, SCAR, STS.

\section{Validation of molecular markers associated to leaf rust resistance genes in wheat}

\begin{abstract}
The objective of this work was to validate molecular markers previously associated to leaf rust resistance genes in Brazilian wheat genotypes. Five STS and SCAR markers identified as associated to the resistance alleles of the genes $L r 1, \operatorname{Lr} 9, \operatorname{Lr} 10$ and $\operatorname{Lr} 24$ were tested by PCR in 25 Brazilian wheat genotypes with known presence or absence of these alleles. The STS marker associated to $L r l$ was not efficient in identifying Brazilian genotypes carrying its resistance allele. The STS and SCAR markers associated to $\operatorname{Lr} 9, \operatorname{Lr} 10$ and Lr24 are efficient in identifying plants carrying the resistance alleles for these genes, and therefore, can be used for marker-assisted selection of leaf rust resistance in Brazilian wheat genotypes.
\end{abstract}

Index terms: Puccinia triticina, Triticum aestivum, SCAR, STS.

\section{Introdução}

A ferrugem-da-folha é uma das moléstias que mais causa prejuízos à triticultura brasileira. A melhor estratégia de controle dessa doença é o uso da resistência genética (Barcellos et al., 2000). Até o momento, foram identificados aproximadamente 50 genes de resistência à ferrugem-da-folha (genes $L r$ ) em trigo (McIntosh et al., 2007). Esses genes podem expressar a resistência em fase de plântula ou em planta adulta. Os que expressam resistência, em fase de plântula, são geralmente de efeito maior no fenótipo e herdados de forma simples. Por outro lado, os que expressam resistência em fase de planta adulta são de efeito menor no fenótipo ou, quando de efeito maior, dependem da interação com outros genes para haver boa expressão da resistência.

A cultivar brasileira de trigo Frontana tem sido a mais usada mundialmente como fonte de resistência à ferrugem-da-folha. Além de possuir os genes $\operatorname{Lr} 13$, Lr34 e T3, identificados como responsáveis, em conjunto, pela maior parte dessa resistência, outros genes de menor efeito parecem estar envolvidos (Roelfs et al., 1992). No Brasil, tornou-se evidente a importância econômica dessa doença quando a cultivar Frontana e outras cultivares portadoras do mesmo tipo de resistência foram substituídas por cultivares suscetíveis, principalmente pela introdução de germoplasma do Centro Internacional de Mejoramiento de Maiz y Trigo. A resistência à essa doença, então, 
passou a receber atenção especial nos programas de melhoramento de trigo (Brammer, 2000).

Vários fatores estão relacionados com a quebra da resistência à ferrugem-da-folha. Esses fatores podem ser ambientais, inerentes ao próprio patógeno, à cultivar e à interação entre eles (Chaves \& Barcellos, 2006). Atualmente, para o controle da ferrugemda-folha, deve-se empregar combinações de genes, independentemente de serem de efeito maior ou menor no fenótipo. Exemplos de combinações efetivas são as presentes na cultivar Frontana $-L r 13+L r 34+T 3$ e mais genes de efeitos menores - e a combinação entre os genes $L r 9$ e $L r 24$ (Roelfs et al., 1992). A combinação de genes de resistência por métodos clássicos de melhoramento tem sido limitada, devido à presença de um gene na planta mascarar o efeito de outro, o que torna difícil à avaliação fenotípica da presença individual de cada gene (Milach \& Cruz, 1997). Assim, o uso de marcadores moleculares, associados a genes que confiram resistência à ferrugemda-folha em trigo, pode aumentar a eficiência da seleção, e possibilita a seleção de caracteres de interesse com base no genótipo.
Marcadores PCR-específicos, tais como STS ("Sequence Tagged Site") ou SCAR ("Sequence Characterized Amplified Region"), estão disponíveis para muitos genes $L r$ (Silva, 2002). No entanto, esses marcadores foram desenvolvidos em genótipos que não são os utilizados hoje em programas de melhoramento de trigo no Brasil. Para possibilitar o uso deles na seleção assistida, é necessário fazer sua validação para genótipos a ser utilizados como fontes de resistência.

O objetivo deste trabalho foi avaliar o potencial de cinco marcadores PCR-específicos, associados aos genes $L r 1, L r 9, L r 10$ e $L r 24$, para uso na seleção assistida para resistência à ferrugem-da-folha, em programas de melhoramento de trigo no Brasil.

\section{Material e Métodos}

Para as análises moleculares foram utilizadas 25 genótipos de trigo, tendo sido 23 cultivares e duas linhagens (OC 9511 e PF 9099) com conhecida presença ou ausência dos alelos de resistência dos genes $\operatorname{Lrl}, \operatorname{Lr} 9, \operatorname{Lr} 10$ e $\operatorname{Lr} 24$ (Tabela 1). A postulação

Tabela 1. Genealogia e postulação de presença ou ausência de alelos de resistência à ferrugem-da-folha, para quatro genes $L r$, em 23 cultivares e duas linhagens de trigo, utilizadas neste trabalho.

\begin{tabular}{|c|c|c|c|c|c|}
\hline \multirow[t]{2}{*}{$\begin{array}{l}\text { Cultivar/ } \\
\text { linhagem }\end{array}$} & \multirow[t]{2}{*}{ Cruzamento } & \multicolumn{4}{|c|}{$\begin{array}{c}\text { Postulação }{ }^{(1)} \text { dos genes } \\
L r \text { analisados } \\
\end{array}$} \\
\hline & & Lrl & $\operatorname{Lr} 9$ & $\operatorname{Lr} 10$ & $\operatorname{Lr} 24$ \\
\hline Anahuac 75 & II 12300//LERMA ROJO 64/8156/3/NORTEÑO 67 & + & - & + & - \\
\hline BR 15 & IAS 54*2/TOKAI 80//PF 69193 & + & - & + & - \\
\hline BR 18 & D 6301/NAINARI 60//WEIQUE/RED MACE/3/CIANO*2/CHRIS,ALD SIB & + & - & + & - \\
\hline BR 23 & CORRE CAMINOS/ ALONDRA SIB/3/IAS 54-20/COTIPORA//CNT 8 & + & - & - & - \\
\hline BR 38 & IAS 55*4/AGENT//IAS 55*4/CI 14123 & - & - & - & + \\
\hline BR 119 & PF82252/BR35//IAPAR17/PF8550 & + & - & + & - \\
\hline CEP 11 & PF $6968 * 2 / H A D D E N$ & + & - & + & - \\
\hline CEP 14 & PEL 72380/ARTHUR 71 & + & + & - & - \\
\hline CEP 24 & BR3/CEP7887//CEP7775/CEP11 & + & + & + & + \\
\hline CEP 27 & CEP 8057/BUTUI//CEP 8324 & + & + & + & + \\
\hline EMBRAPA 16 & HULHA NEGRA/CNT 7//AMIGO/CNT 7 & - & - & - & + \\
\hline EMBRAPA 52 & HULHA NEGRA/CNT 7//AMIGO/CNT 7 & - & - & - & + \\
\hline IAC 5 & FRONTANA/KENYA 58//PG 1 & - & - & - & - \\
\hline IAPAR 6 & DESCONHECIDO & + & - & + & - \\
\hline IAPAR 17 & JUPATECO 73/BLUE JAY SIB & + & - & + & - \\
\hline IAPAR 29 & BLUE JAY SIB/JUPATECO 73, OPATA 85 & + & - & + & - \\
\hline IAPAR 60 & BJY"S"/JUP//TAN"S" & + & - & + & - \\
\hline OC $9511^{*}$ & PG 864/IOC 856 & + & - & + & - \\
\hline OCEPAR 14 & IAS 64/ALDAN SIB/6/COC 75/5/PICHON/4/KT 54*2/N 10B//K 54B/3/NAR 59 & + & - & + & - \\
\hline OCEPAR 16 & SISKIN SIB/VEERY SIB & + & - & + & - \\
\hline OCEPAR 21 & CEP 11/4/KALYAN/BLUEBIRD//CAJEME SIB/3/ALONDRA SIB & + & - & + & - \\
\hline OCEPAR 23 & IAC 5/ALDAN SIB//CEP 7780 & + & - & + & + \\
\hline Peladinho & DESCONHECIDO & - & - & - & - \\
\hline PF 9099 & PF 82252/BR 35//IAPAR 17/PF 8550 & + & - & + & - \\
\hline Rubi & PF 869107/KLH 3450 C 3131 & + & - & + & + \\
\hline
\end{tabular}

${ }^{(1)}$ Postulação de acordo com Zoldan (1998): +, presença e -, ausência de alelos de resistência para os respectivos genes $L r$. 
desses alelos de resistência nesses genótipos foi realizada por Zoldan (1998). As sementes dos genótipos foram germinadas em placas de Petri com papel germinador umedecido e mantidas no escuro em câmara de germinação. Após os coleóptilos atingirem aproximadamente $6 \mathrm{~cm}$, eles foram macerados em nitrogênio líquido e mantidos a $-20^{\circ} \mathrm{C}$, até o momento da extração do DNA.

O DNA foi extraído de acordo com o protocolo proposto por Murray \& Thompson (1980), com as seguintes modificações: aproximadamente $50 \mathrm{mg}$ de tecido foram macerados em nitrogênio líquido e, em seguida, foi adicionado $600 \mu \mathrm{L}$ de tampão de extração (CTAB 1\%(m V $\left.{ }^{-1}\right), \mathrm{NaCl} 1,4 \mathrm{mM}$, EDTA $20 \mathrm{mM}$, Tris-HCl $100 \mathrm{mM}$ pH 8,0) pré-aquecido a $65^{\circ} \mathrm{C}$. $\mathrm{O}$ tecido foi incubado a $65^{\circ} \mathrm{C}$ no tampão de extração por $60 \mathrm{~min}$. O DNA foi separado dessa solução com fenol-clorofórmio: álcool-isoamílico (24:1) e centrifugação. O DNA foi precipitado com etanol a $-20^{\circ} \mathrm{C}$, e ressuspenso em TE (Tris- $\mathrm{HCl} 10 \mathrm{mM} \mathrm{pH} \mathrm{8,0,}$ EDTA $1 \mathrm{mM}$ ), e tratado com RNase A. Depois de seco, o DNA foi solubilizado em água ultrapura e quantificado em espectrofotômetro (Spectronic Genesys).

Para as análises moleculares, foram sintetizados primers para os marcadores STS-Lr1, STS-Lr9, STS-Lr10, STS-Lr24 e SCAR-Lr24 (Tabela 2). Esses primers foram utilizados para amplificação por PCR ("Polymerase Chain Reaction" - reação em cadeia da polimerase) do DNA de 25 genótipos de trigo, com conhecida presença ou ausência dos alelos de resistência dos genes $L r 1, L r 9, L r 10$ e $L r 24$. Para a PCR, foi preparada solução com $25 \mathrm{ng}$ de DNA, tampão (Tris $\mathrm{HCl} 20 \mathrm{mM}, \mathrm{KCl} 50 \mathrm{mM}), \mathrm{MgCl}_{2}(1,5 \mathrm{mM})$, dNTP ( $0,8 \mathrm{mM}$ de cada), primer direto ( $20 \mathrm{ng}$ ), primer reverso $(20 \mathrm{ng})$, Taq DNA polymerase (1 U) e água ultrapura até completar um volume de $25 \mu \mathrm{L}$. As amplificações foram conduzidas em termociclador de acordo com o protocolo estabelecido na literatura para cada marcador (Tabela 2). Os produtos das amplificações foram resolvidos em gel de agarose a $1,4 \%$, e corados com brometo de etídio, e visualizados sob luz ultravioleta. As amostras de cada genótipo foram aplicadas no gel em ordem aleatória, e foram feitas três repetições independentes no tempo.

\section{Resultados e Discussão}

$\mathrm{O}$ gene $\operatorname{Lr} 1$ que confere resistência à ferrugemda-folha é originário do próprio genoma do trigo hexaplóide e foi descrito por Ausemus et al. (1946). Esse gene encontra-se mapeado na região distal do braço longo do cromossomo 5D (Somers et al., 2004). Feuillet et al. (1995) desenvolveram um marcador STS a partir da conversão de um marcador RFLP ("Restriction Fragment Length Polymorphism") que, na população desenvolvida, co-segregou com o alelo de resistência desse gene. Ao analisar o marcador STS, nos 25 genótipos brasileiros de trigo, com presença ou ausência do alelo de resistência do gene Lrl, 19 apresentaram amplificação, incluindo os genótipos IAC 5 e Peladinho, que não possuem o alelo de resistência (Figura 1). Urbanovich et al. (2006), ao analisar esse marcador STS, em 68 genótipos oriundos de várias regiões do mundo, exceto Brasil, também observaram a amplificação do fragmento de tamanho esperado em genótipos com ausência do alelo de resistência para esse gene. Chelkowski et al. (2003), ao analisar esse mesmo marcador em diferentes isolinhas da cultivar Thatcher, também observaram que ele não era específico para as linhagens com o alelo de resistência do gene $\mathrm{Lrl}$. Esses dados corroboram os encontrados neste trabalho, e confirmam que esse

Tabela 2. Marcadores moleculares associados aos genes $\operatorname{Lr} 1, \operatorname{Lr} 9, \operatorname{Lr} 10$ e $\operatorname{Lr} 24$ de resistência à ferrugem-da-folha em trigo.

\begin{tabular}{|c|c|c|c|}
\hline Marcador & Primers & Fragmento & Referência \\
\hline STS-Lr1 & $\begin{array}{l}\text { R 5' - ccttgccagcccaaaag }-3^{\prime} \\
\text { L 5'- gggtcacgtactactata }-3^{\prime}\end{array}$ & $560 \mathrm{pb}$ & Feuillet et al. (1995) \\
\hline STS-Lr9 & $\begin{array}{l}\text { R 5'-ccacactaccccaaagagacg-3' } \\
\text { L 5'- tccttttattccgcacgecgg }-3 \text { ' }\end{array}$ & $1.100 \mathrm{pb}$ & Schachermayr et al. (1994) \\
\hline STS-Lr10 & $\begin{array}{l}\text { R 5'- gctcgtcatctccacagg }-3 \text {, } \\
\text { L 5'- acctcatgcggatgtag }-3 \text { ', }\end{array}$ & $850 \mathrm{pb}$ & Schachermayr et al. (1997) \\
\hline STS-Lr24 & $\begin{array}{l}\text { R 5'- agtcgtccccgaagacccgetgga }-3^{\prime} \\
\text { L 5' - tcgtcccetgatgecatgtaatgt }-3 \text {, }\end{array}$ & $350 \mathrm{pb}$ & Dedryver et al. (1996) \\
\hline SCAR-Lr24 & $\begin{array}{l}\text { R 5' - tctagtctgtacatgggggc }-3 \text {, } \\
\text { L 5'- tggcacatgaactccatacg }-3 \text {, }\end{array}$ & $700 \mathrm{pb}$ & Schachermayr et al. (1995) \\
\hline
\end{tabular}


marcador não apresenta potencial de uso em seleção assistida para o alelo de resistência do gene $L r l \mathrm{em}$ populações recombinantes diferentes das quais foi desenvolvido.

O gene $L r 9$, originário de Aegilops umbellulata, foi introduzido no trigo hexaplóide por Sears (1956) e encontra-se mapeado no braço longo do cromossomo 6B (Somers et al., 2004). Um marcador STS que segrega a $8 \mathrm{cM}$ desse gene foi desenvolvido pela conversão de um marcador RAPD ("Random Amplification of Polymorphic DNA") (Schachermayr et al., 1994). Pela análise desse marcador nos genótipos brasileiros de trigo observou-se que, entre os três genótipos com conhecida presença do alelo de resistência do gene $\operatorname{Lr} 9$ - CEP14, CEP24 e CEP27 -, o genótipo CEP14 apresentou amplificação do fragmento de tamanho esperado de $1.100 \mathrm{pb}$ (Figura 2). Nenhum dos genótipos com ausência do alelo de resistência do gene $\operatorname{Lr} 9$ apresentou amplificação de fragmento de tamanho esperado. Blaszczyk et al. (2005) testaram esse marcador em um grupo de genótipos com conhecida presença e ausência do alelo de resistência do gene $L r 9$, em sete diferentes laboratórios europeus. Em todos, o marcador foi específico para plantas que possuem o alelo de resistência, o que mostra a robustez desse marcador. Outros trabalhos têm relatado a especificidade do marcador STS em identificar plantas com o alelo de resistência de gene $\operatorname{Lr} 9$ (Singh et al., 2003; Stepien et al., 2003). Nesses trabalhos, o marcador não apresentou amplificação em nenhuma planta com ausência do alelo de resistência. O mesmo ocorreu no presente trabalho, portanto esse marcador apresenta grande potencial para uso em seleção assistida para o alelo de resistência do gene $\operatorname{Lr} 9$ em programas de melhoramento de trigo no Brasil. Porém, antes de utilizá-lo para a seleção assistida, é preciso verificar

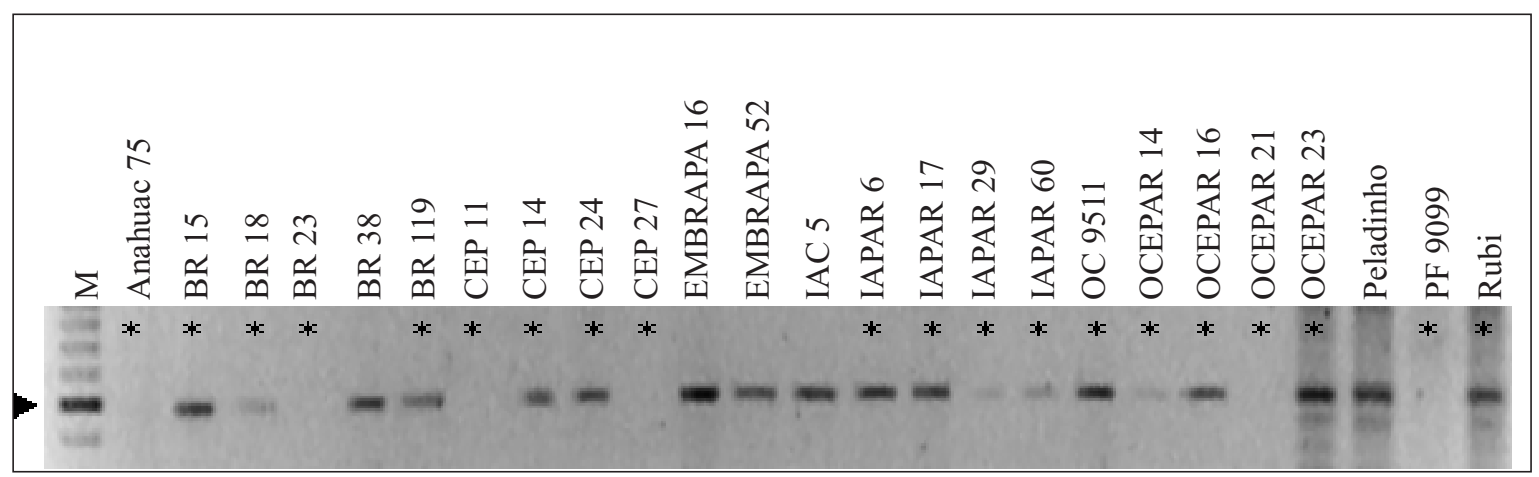

Figura 1. Padrão de amplificação do marcador STS-Lr1 nos 25 genótipos brasileiros de trigo analisados. *Cultivares nas quais o alelo de resistência do gene Lrl foi postulado por Zoldan (1998); a seta à esquerda indica o fragmento de $560 \mathrm{pb}$ potencialmente associado ao gene Lrl. M, marcador de peso molecular DNA Ladder de $100 \mathrm{pb}$.

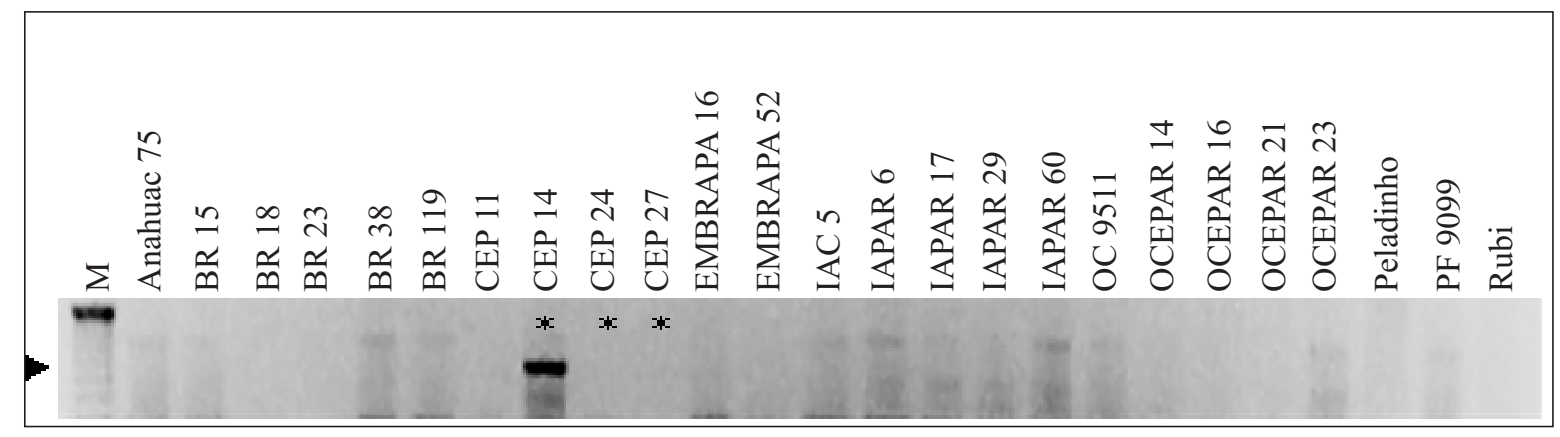

Figura 2. Padrão de amplificação do marcador STS-Lr9 nos 25 genótipos brasileiros de trigo analisados. *Genótipos nos quais o alelo de resistência do gene $\operatorname{Lr} 9$ foi postulado por Zoldan (1998). A seta à esquerda indica o fragmento de $1.100 \mathrm{pb}$ potencialmente associado ao gene $\operatorname{Lr} 9$. M, marcador de peso molecular DNA Ladder de $100 \mathrm{pb}$. 
se o genótipo que possui o alelo de resistência do gene Lr 9 ainda mantém esse marcador em associação, pois essa associação pode ter sido quebrada por meio de recombinação, como no caso dos genótipos CEP 24 e CEP 27.

O gene $\operatorname{Lr} 10$ é originário do genoma do próprio trigo hexaplóide e está mapeado no braço curto do cromossomo 1A (Feuillet et al., 2004). Um marcador STS foi desenvolvido pela conversão de um marcador RFLP que co-segrega com esse gene (Schachermayr et al., 1997). No presente trabalho, esse marcador apresentou amplificação em 11 dos 18 genótipos com presença do alelo de resistência do gene $\mathrm{Lr} 10$ (Figura 3). Nenhum dos genótipos com ausência do alelo de resistência do gene $\operatorname{Lrl0}$ apresentou amplificação, o que mostra alto potencial de uso do marcador STS na seleção assistida para esse alelo de resistência. Stepien et al. (2003), ao analisar 37 cultivares européias de trigo, também concluíram que esse marcador foi eficiente na identificação de cultivares que contêm o alelo de resistência do gene $\operatorname{Lr} 10$. O teste desse marcador, em sete diferentes laboratórios europeus, também permitiu a comprovação de sua eficácia (Blaszczyk et al., 2005). Da mesma forma que para $L r 9$, é preciso verificar se a associação entre marcador e alelo de resistência permanece efetiva para cada genótipo de interesse antes da implantação de uma rotina de seleção assistida.

O gene $\operatorname{Lr} 24$ foi transferido para o trigo hexaplóide do Agropyron elongatum por translocação de parte do cromossomo 3D (Smith et al., 1968). Dois marcadores PCR-específicos foram desenvolvidos associados a esse gene, sendo um SCAR (Schachermayr et al., 1995) e um STS (Dedryver et al., 1996). Pela análise do marcador SCAR nos genótipos brasileiros de trigo, observou-se que, entre os sete genótipos nos quais o alelo de resistência do gene $L r 24$ foi postulado, em três ele apresentou amplificação (Figura 4 A). O marcador STS apresentou amplificação nos mesmos três genótipos (Figura 4 B). Ambos os marcadores apresentaram amplificação no genótipo IAPAR 60, no qual o gene não foi postulado. As análises desses marcadores, em 37 genótipos europeus de trigo (Stepien et al., 2003), em um grupo de isolinhas (Chelkowski et al., 2003) e em genótipos de trigo de várias regiões do mundo (Urbanovich et al., 2006), demonstram a especificidade desses marcadores em identificar somente plantas que contêm o alelo de resistência do gene Lr24. Zoldan (1998) afirma que IAPAR 60 apresenta outros genes de resistência à ferrugem-da-folha que não foram possíveis postular. Os resultados do presente trabalho sugerem que o genótipo IAPAR 60 possui o alelo de resistência do gene $L r 24$. Assim, esses dois marcadores PCR-específicos têm grande potencial de uso na seleção assistida para o gene $L r 24$ no Brasil.

Os genes Lrl e Lrl0 são os mais comuns nas cultivares brasileiras de trigo (Zoldan, 1998). Esses genes não têm sido eficientes na resistência quando sozinhos ou combinados entre si, no entanto parecem influenciar positivamente na resistência quando combinados com outros genes $\operatorname{Lr}$ (MacIntosh et al., 1995). Embora o gene $\operatorname{Lr} 9$ não esteja amplamente distribuído nos genótipos cultivados, em razão da presença de ligações gênicas indesejáveis, oriundo de Aegilops umbellulata, levar a uma diminuição no rendimento (Ortelli et al., 1996), ele tem sido muito efetivo contra a ferrugem-da-folha nos países europeus

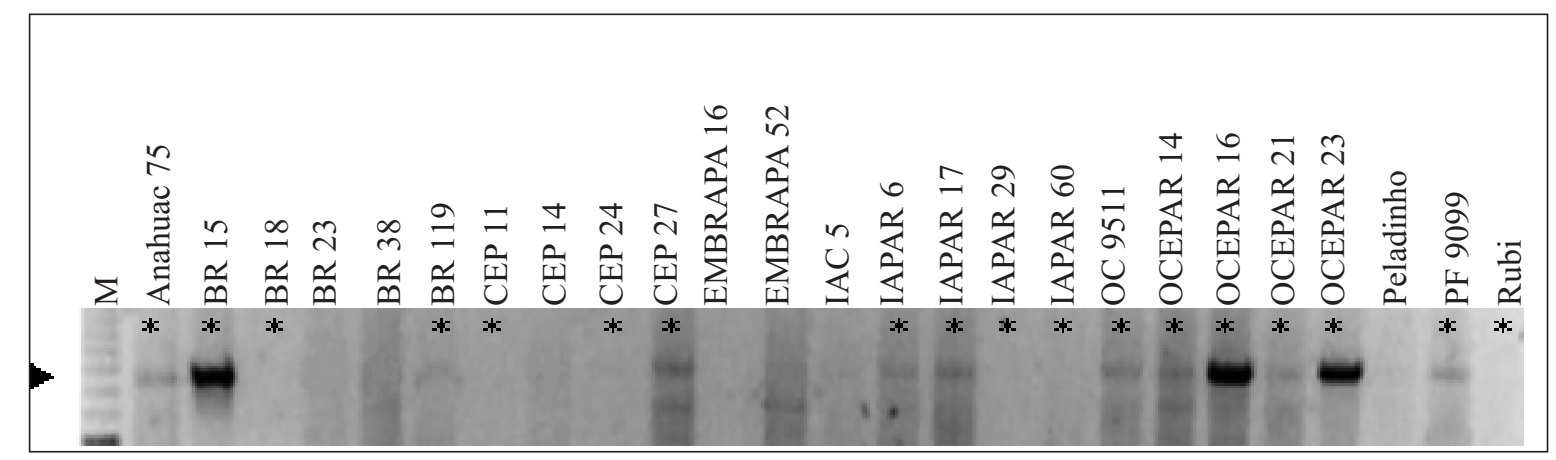

Figura 3. Padrão de amplificação do marcador STS-Lr10 nos 25 genótipos brasileiros de trigo analisados. *Genótipos nos quais o alelo de resistência do gene Lr10 foi postulado por Zoldan (1998). A seta à esquerda indica o fragmento de $850 \mathrm{pb}$ potencialmente associado ao gene $\operatorname{Lr} 10$. M, marcador de peso molecular DNA Ladder de $100 \mathrm{pb}$. 


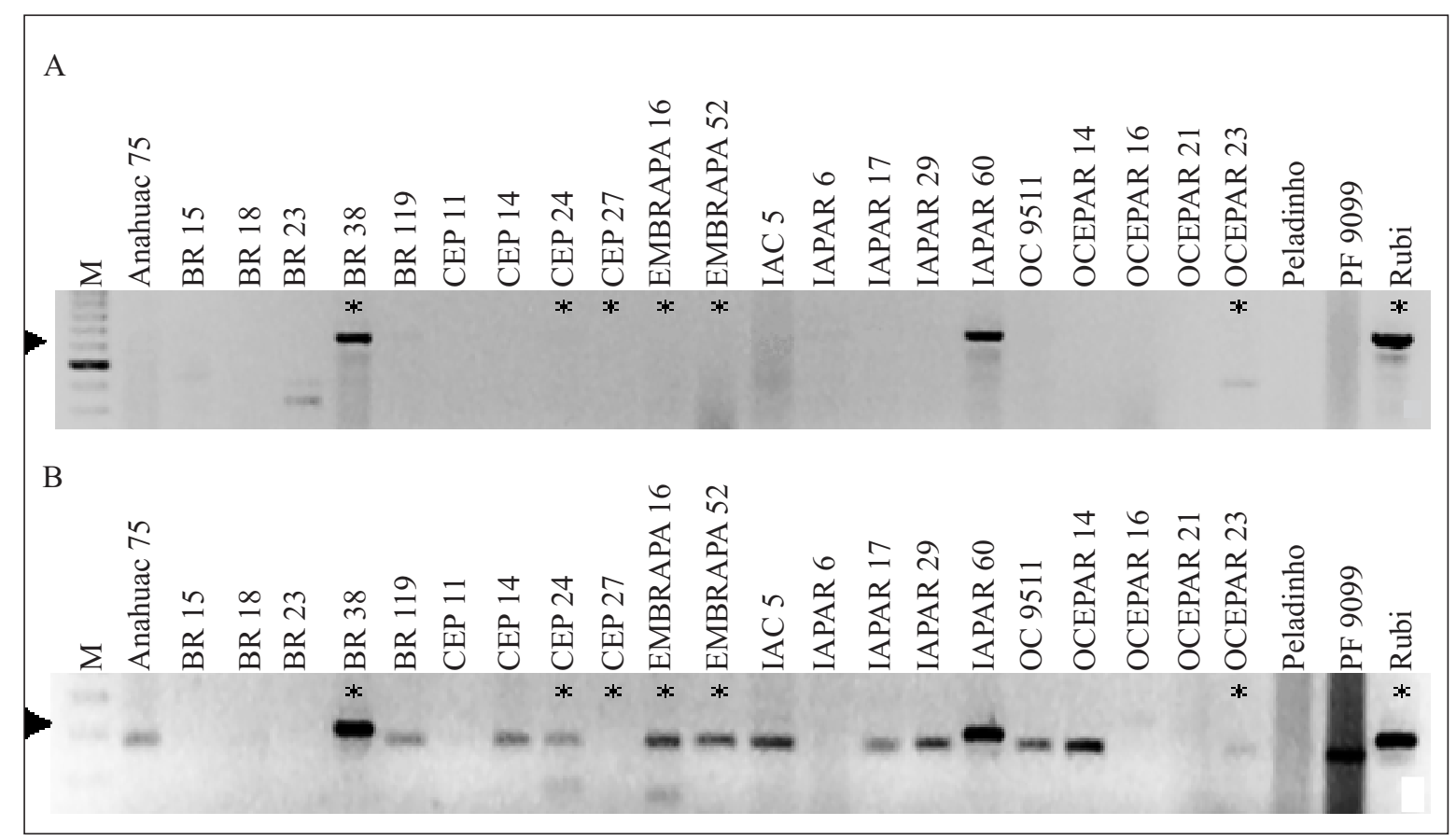

Figura 4. Padrão de amplificação dos marcadores associados ao gene $L r 24$ nos 25 genótipos brasileiros de trigo analisados. *Genótipos nos quais o alelo de resistência do gene $\operatorname{Lr} 10$ foi postulado por Zoldan (1998). As setas à esquerda indicam os fragmentos de $700 \mathrm{pb}(\mathrm{A})$ e $350 \mathrm{pb}(\mathrm{B})$, potencialmente associados ao gene $\operatorname{Lr} 24$. A, padrão de amplificação do marcador SCAR-Lr24; B, padrão de amplificação do marcador STS-Lr24. M, marcador de peso molecular DNA Ladder de $100 \mathrm{pb}$.

(Urbanovich et al., 2006). Outro aspecto interessante desse gene é que, na combinação com o gene $\operatorname{Lr} 24$, tem sido altamente efetivo na resistência à ferrugemda-folha (Roelfs et al., 1992). No Brasil, ele tem sido pouco explorado, pois está presente somente em três genótipos testados (Tabela 1). O marcador aqui validado, associado ao alelo de resistência do gene $\operatorname{Lr} 9$, facilitará a introdução desse gene em novas cultivares de trigo e sua combinação com outros de resistência.

Os marcadores validados neste trabalho, associados aos alelos de resistência dos genes $L r 9, L r 10$ e $L r 24$, são específicos para genótipos que apresentam esses alelos, no entanto há genótipos com presença do alelo e ausência do marcador (Tabela 1, Figuras 2, 3 e 4). Desta maneira, o uso desses marcadores estão limitados aos cruzamentos em que os genótipos são contrastantes para o alelo de resistência e o marcador. Em cruzamentos em que os genótipos não foram avaliados, é recomendada uma avaliação prévia dos marcadores para verificar a amplificação no genótipo resistente e ausência de amplificação no genótipo suscetível. O marcador STS-Lr24 apresenta uma banda nos genótipos suscetíveis de tamanho muito próximo ao fragmento associado ao alelo de resistência do gene Lr9 (Figura 4 B). Assim, é recomendado a resolução dos produtos de amplificação desse marcador em gel de agarose no máximo a $1 \%$ e, e um tempo de corrida de, no mínimo, duas horas a $110 \mathrm{~V}$.

Os marcadores STS e SCAR validados neste trabalho representam uma nova ferramenta que poderá auxiliar os programas de melhoramento genético de trigo no Brasil a combinar vários genes em uma cultivar de forma rápida, precisa e com baixo custo e, assim, obter novas cultivares com resistência à ferrugem-da-folha de forma mais eficiente.

\section{Conclusões}

1. O marcador STS, associado ao gene $\operatorname{Lrl}$, não apresenta potencial para uso na seleção assistida em genótipos brasileiros de trigo.

2. Os marcadores STS e SCAR, associados aos genes $L r 9, L r 10$ e $L r 24$, apresentam potencial para uso na seleção assistida em genótipos brasileiros de trigo. 


\section{Agradecimentos}

À Coordenação de Aperfeiçoamento de Pessoal de Nível Superior e ao Conselho Nacional de Desenvolvimento científico e Tecnológico, pelas bolsas concedidas; ao Programa de Apoio ao Desenvolvimento Científico e Tecnológico, pelo recurso financeiro para desenvolvimento do projeto.

\section{Referências}

AUSEMUS, E.R.; HARRINGTON, J.B.; REITZ, L.P.; WORZELLA, W.W. A summary of genetic studies in hexaploid and tetraploid wheats. Journal of the American Society of Agronomy, v.38, p.1082-1099, 1946.

BARCELLOS, A.L.; ROELFS, A.P.; MORAES-FERNANDES, M.I.B. Inheritance of adult plant leaf rust resistance in the Brazilian wheat cultivar Toropi. Plant Disease, v.84, p.90-93, 2000.

BLASZCZYK, L.; TYRKA, M.; CHELKOWSKI, J. ${ }^{P s t}$ AFLP based markers for leaf rust resistance genes in common wheat. Journal of Applied Genetics, v.46, p.357-364, 2005.

BRAMMER, S.P. Mapeamento de genes de resistência parcial à ferrugem-da-folha em cultivares brasileiras de trigo (Triticum aestivum L. em Thell). 2000. 105p. Tese (Doutorado) Universidade Federal do Rio Grande do Sul, Porto Alegre.

CHAVES, M.S.; BARCELLOS, A.L. Especialização fisiológica de Puccinia triticina no Brasil em 2002. Fitopatologia Brasileira, v.31, p.57-62, 2006.

CHELKOWSKI, J.; GOLKA, L.; STEPIEN, L. Application of STS markers for leaf rust resistance genes in near-isogenic lines of spring wheat cv. Thatcher. Journal of Applied Genetics, v.44, p.323-338, 2003.

DEDRYVER, F.; JUBIER, M.F.; THOUVENIN, J.; GOYEAU, H. Molecular markers linked to the leaf rust resistance gene Lr24 in different wheat cultivars. Genome, v.39, p.830-835, 1996.

FEUILLET, C.; MESSMER, M.; SCHACHERMAYR, G.; KELLER, B. Genetic and physical characterization of the $L r l$ leaf rust resistance locus in wheat (Triticum aestivum L.). Molecular and General Genetics, v.248, p.553-562, 1995.

FEUILLET, C.; TRAVELLA, S.; STEIN, N.; ALBAR, L.; NUBLAT, A.; KELLER, B. Map-based isolation of the leaf rust disease resistance gene $\mathrm{Lr} 10$ from the hexaploid wheat (Triticum aestivum L.) genome. Proceedings of the National Academy of Sciences of United States of America, v.100, p.15253-15258, 2003.

MCINTOSH, R.A.; APPELS, R.; DEVOS, K.M.; DUBCOVSKY, J.; ROGERS, W.J.; YAMAZAKI, Y. Catalogue of gene symbols for wheat. 2007. 31p. Disponível em: <http://www.shigen.nig. ac.jp/wheat/komugi/genes/macgene/supplement2007.pdf $>$. Acesso em: 10 fev. 2008.

MCINTOSH, R.A.; WELLINGS, C.R.; PARK, R.F. Wheat rusts: an atlas of resistance genes. Melbourne: CSIRO, 1995. 200p.
MILACH, S.C.K.; CRUZ, R.P. da. Piramidização de genes de resistência às ferrugens em cereais. Ciência Rural, v.27, p.685-689, 1997.

MURRAY, M.G.; THOMPSON, W.F. Rapid isolation of highmolecular-weigth plant DNA. Nucleic Acids Research, v.8, p.4321-4325, 1980.

ORTELLI, S.; WINZELER, H.; WINZELER, M.; FRIEDY, P.M.; NÖSBERGER, J. Leaf rust resistance gene $\operatorname{Lr} 9$ and winter wheat yield reduction: I. Yield and yield components. Crop Science, v.36, p.1590-1595, 1996.

ROELFS, A.P.; SINGH, R.P.; SAARI, E.E. Rust diseases of wheat: concepts and methods of disease management. Mexico: Cimmyt, 1992. 81p.

SCHACHERMAYR, G.; FEUILLET, C.; KELLER, B. Molecular markers for the detection of the wheat leaf rust resistance gene Lr10 in diverse genetic backgrounds. Molecular Breeding, v.3, p.65-74, 1997.

SCHACHERMAYR, G.; SIEDLER, H.; GALE, M.D.; WINZELER, H.; WINZELER, M.; KELLER, B. Identification and localization of molecular markers linked to the $\operatorname{Lr} 9$ leaf rust resistance gene of wheat. Theoretical and Applied Genetics, v.88, p.110-115, 1994.

SCHACHERMAYR, G.M.; MESSMER, M.M.; FEUILLET, C.; WINZELER, H.; WINZELER, M.; KELLER, B. Identification of molecular markers linked to the Agropyron elongatum-derived leaf rust resistance gene $L r 24$ in wheat. Theoretical and Applied Genetics, v.90, p.982-990, 1995.

SEARS, E.R. The transfer of leaf-rust resistance from Aegilops umbellulata into wheat Neurospora. Brookhaven Symposia in Biology, v.9, p.1-21, 1956.

SILVA, P.R. da. Identificação e conversão de marcadores moleculares associados à resistência à ferrugem-da-folha em trigo. 2002. 64p. Dissertação (Mestrado) - Universidade Federal do Rio Grande do Sul, Porto Alegre.

SINGH, R.; TIWARI, R.; DATTA, D. Detection of leaf rust resistance genes $L r 9$ and $L r 10$ in wheat (Triticum aestivum) by PCR based STS markers. Acta Phytopathologica et Entomologica Hungarica, v.38, p.245-249, 2003.

SMITH, E.L.; SCHLEHUBER, A.M.; YOUNG JUNIOR, H.C.; EDWARDS, L.H. Registration of "Agent" wheat. Crop Science, v.8, p.511-512, 1968.

SOMERS, D.J.; ISAAC, P.; EDWARDS, K. A high-density microsatellite consensus map for bread wheat (Triticum aestivum L.). Theoretical and Applied Genetics, v.109, p.1105-1114, 2004.

STEPIEN, L.; GOLKA, L.; CHELKOWSKI, J. Leaf rust resistance genes of wheat: identification in cultivars and resistance sources. Journal of Applied Genetics, v.44, p.139-149, 2003.

URBANOVICH, O.Y.; MALYSHEV, S.V.; DOLMATOVICH, T.V.; KARTEL, N.A. Identification of leaf rust resistance genes in wheat (Triticum aestivum L.) cultivars using molecular markers. Russian Journal of Genetics, v.42, p.546-554, 2006.

ZOLDAN, S.M. Identificação de genes de resistência à ferrugemda-folha em cultivares brasileiras de trigo (Triticum aestivum L. em Thell). 1998. 83p. Dissertação (Mestrado) - Universidade de Passo Fundo, Passo Fundo. 